\title{
Triterpenoidal Saponins from the Barks of Zygophyllum fabago L.
}

\author{
Yu-Lin FenG,${ }^{a, b}$ Bei Wu, ${ }^{c}$ He-Ran LI, ${ }^{d}$ Yun-Qiu LI,${ }^{b}$ Li-Zhen Xu, ${ }^{*, b}$ Shi-Lin YAnG, ${ }^{*, a}$ and \\ Susumu KITANAKA ${ }^{d}$
}

\begin{abstract}
${ }^{a}$ National Pharmaceutical Engineering Centre for Solid Preparation in Chinese Herbal Medicine, Jiangxi University of Traditional Chinese Medicine; Nanchang 330006, P. R. China: ${ }^{b}$ Institute of Medicinal Plant Development, Chinese Academy of Medical Sciences \& Peking Union Medical College; Beijing 100094, P. R. China: ${ }^{c}$ Nanchang Institute for Drug Control; Nanchang 330029, P. R. China: and ${ }^{d}$ College of Pharmacy, Nihon University; 7-7-1 Narashinodai, Funabashi, Chiba 274-8555, Japan.
\end{abstract}

Received January 1, 2008; accepted February 20, 2008; published online March 6, 2008

\begin{abstract}
Two new triterpenoid saponins, zygophylosides $O(1)$ and $P(2)$, have been isolated from the barks of Zygophyllum fabago $\mathrm{L}$. Their structures were elucidated as $3 \beta$-[(2- $O$-sulfo- $\beta$-D-xylopyranosyl)oxy]urs-12-ene-27,28dioic acid and $3 \beta$-[(2- $O$-sulfo- $\beta$-D-xylopyranosyl)oxy]urs-12-ene-27,28-dioic acid 28- $\beta$-D-glucopyranoside, respectively, by spectral and chemical evidence. Compound 1 showed weaker Nitric Oxide (NO) inhibitory activity.
\end{abstract}

Key words Zygophyllum fabago L.; triterpenoid saponin; zygophyloside O; zygophyloside P; nitric oxide

Zygophyllum fabago L. belongs to the Zygophyllaceae family and is mainly distributed in the Gansu provinces and Xinjiang autonomous region of China. It is used as antitussive, expectorant, anti-inflammatory and removing pains. ${ }^{1)}$ In the present work, two new triterpenoid saponins, zygophylosides $\mathrm{O}(\mathbf{1})$ and $\mathrm{P}(\mathbf{2})$, were isolated from the ethanol extract of the barks of this plant. Both of these saponins contain a sulfate group linked to the $\mathrm{C}-2$ oxygen of the $\beta$-D-xyloside moiety. The presence of a sulphate group in $Z$. pinquum ${ }^{2)}$ and $Z$. proinquum $^{3)}$ has already been reported, which provides a biogenetic basis for the presence of a sulfate group in the saponins isolated from Zygophyllum fabago L. The structures of 1 and 2 were elucidated with the help of spectral and chemical methods.

Compound 1 was isolated as white powder. Its molecular formula was determined as $\mathrm{C}_{35} \mathrm{H}_{54} \mathrm{O}_{12} \mathrm{~S}$ by HR-ESI-MS, showing a $[\mathrm{M}+\mathrm{K}]^{+}$peak at $m / z 737.2979$, corresponding to nine degrees of unsaturation. The ESI mass spectrum of 1 exhibited the $[\mathrm{M}+\mathrm{Na}]^{+}$ion $(m / z 721)$ and the $[\mathrm{M}+\mathrm{H}]^{+}$ion $\left(m / z\right.$ 699). The fragment ion at $m / z 509[721-132-80]^{+}$ showed the sequential loss of a pentose moiety plus $\mathrm{SO}_{3}$. The IR spectrum with absorption bands at 1254 and $1225 \mathrm{~cm}^{-1}$ indicated the presence of a sulfate group in $\mathbf{1}$. The ${ }^{13} \mathrm{C}$-NMR spectral data, summarized in Table 1, showed 35 carbon resonances, indicating the presence of a single sugar moiety with a triterpenoid aglycone. The ${ }^{1} \mathrm{H}-\mathrm{NMR}$ spectrum (Table 1) indicated the presence of four tertiary and two secondary methyl groups at $\delta 1.20(3 \mathrm{H}-23), 1.08(3 \mathrm{H}-24), 0.81(3 \mathrm{H}-$ $25), 1.05(3 \mathrm{H}-26)$ and doublets at $\delta 1.19(3 \mathrm{H}, \mathrm{d}, J=6 \mathrm{~Hz}, \mathrm{H}-$ 29), $0.79(3 \mathrm{H}, \mathrm{d}, J=6 \mathrm{~Hz}, \mathrm{H}-30)$. The ${ }^{13} \mathrm{C}-\mathrm{NMR}$ spectrum of the aglycone showed two olefinic carbons at $\delta 134.2(\mathrm{C}-13)$ and 128.9 (C-12) and two carboxyl carbon at $\delta 178.1$ (C-27) and 180.6 (C-28). The heteronuclear multiple bond correlation (HMBC) spectrum showed the correlations for $\mathrm{H}-11 / \mathrm{C}$ 13, H-18/C-12, H-12/C-9, H-18/C-28, H-22/C-28, H-15/C27. The signals of the axial and equatorial oriented protons of the quinovic acid were assigned by the nuclear Overhauser effect spectroscopy (NOESY) experiments. The value of the coupling constant between H-18 and H-19 $\left({ }^{3} J_{18,19}=11.4 \mathrm{~Hz}\right)$ indicated that both protons were in an axial position. This and the NOESY cross peak between $\mathrm{H}-19$ and $\mathrm{H}-16_{\mathrm{ax}}$ showed the cis-connection of the rings D and E. A compari- son between the ${ }^{13} \mathrm{C}-\mathrm{NMR}$ spectral data of 1 and $3-O-[\beta-\mathrm{D}-$ glucopyranosyl]-quinovic acid revealed that the carbon signals of the aglycone of the two molecules were almost identical, suggesting the aglycone was quinovic acid. ${ }^{4}$ The acid hydrolysis afforded quinovic acid as aglycone. The HMBC correlation between $\mathrm{H}-1^{\prime}$ of the sugar moiety at $\delta 4.80$ and $\mathrm{C}-3$ of the aglycone at $\delta 89.4$ revealed that the sugar was attached at $\mathrm{C}-3$ of the aglycone. The anomeric proton signal was observed at $\delta 4.80\left(1 \mathrm{H}, \mathrm{d}, J=7.2 \mathrm{~Hz}, \mathrm{H}-1^{\prime}\right)$ showed the $\beta$-configuration of sugar moiety. The ${ }^{13} \mathrm{C}$-NMR signals at $\delta$ $104.5,80.1,77.1$ and 70.6 can be correlated with ${ }^{1} \mathrm{H}-\mathrm{NMR}$ signals at $\delta 4.80,4.98,4.36$ and 4.15 , respectively. The ${ }^{13} \mathrm{C}$-NMR signals at $\delta 65.8$ can be correlated with ${ }^{1} \mathrm{H}-\mathrm{NMR}$ signals at $\delta 4.23$ and 3.65. Starting from the anomeric proton signal, the other signals of the protons of $\beta$-D-xylose moiety could be assigned by ${ }^{1} \mathrm{H}-{ }^{1} \mathrm{H}$ correlation spectroscopy $\left({ }^{1} \mathrm{H}-{ }^{1} \mathrm{H} \mathrm{COSY}\right)$, heteronuclear multiple quantum correlation (HMQC) and HMBC spectrum. The configuration of the sugar unit was assigned after hydrolysis of 1 with $2 \mathrm{M} \mathrm{HCl}$. The sugar unit of $\mathbf{1}$ was determined to be D-xylose. The downfield shifts of the H-2' xylose $(\Delta \delta+1.00)$ and C-2' xylose $(\Delta \delta+5.3)$ signals of 1 compared with a nonsubstituted moiety indicate that the sulphate group is in position $\mathrm{C}-2^{\prime}$ of the xylose. The above structural elucidation of 1 was further supported by its ${ }^{1} \mathrm{H}-{ }^{1} \mathrm{H}$ COSY, HMQC and HMBC data. From these results, the structure of 1 (Fig. 1) was established as $3 \beta$-[(2- $O$-sulfo- $\beta$-D-xylopyranosyl)oxy]urs-12-ene-27,28dioic acid.

Compound 2 was isolated as white powder. Its molecular formula was determined as $\mathrm{C}_{41} \mathrm{H}_{64} \mathrm{O}_{17} \mathrm{~S}$ by HR-ESI-MS, showing a $[\mathrm{M}+\mathrm{Na}]^{+}$peak at $m / z 883.3779$, corresponding to ten degrees of unsaturation. The ESI mass spectrum of 1 exhibited the $[\mathrm{M}+\mathrm{Na}]^{+}$ion $(m / z 883)$ and the $[\mathrm{M}+\mathrm{H}]^{+}$ion $\left(m / z\right.$ 861). The fragment ions at $m / z 671$ [883-132-80] ${ }^{+}$, $464[671-162-45]^{+}$showed the sequential loss of a pentose moiety plus $\mathrm{SO}_{3}$ and the presence of two sugar moieties. The IR spectrum with absorption bands at 1250 and $1223 \mathrm{~cm}^{-1}$ indicated the presence of a sulfate group in $\mathbf{2}$. The configuration of the sugar unit was assigned after hydrolysis of $\mathbf{2}$ with $2 \mathrm{M} \mathrm{HCl}$. The acid hydrolysis afforded D-xylose and D-glucose and quinovic acid as aglycone. The ${ }^{13} \mathrm{C}$-NMR spectrum (Table 1) of 2 showed two anomeric signals which appeared 
Table 1. ${ }^{1} \mathrm{H}$ - and ${ }^{13} \mathrm{C}-\mathrm{NMR}$ Spectral Data for Compounds $\mathbf{1}$ and $\mathbf{2}$ in Pyridine- $d_{5}$

\begin{tabular}{|c|c|c|c|c|}
\hline \multirow{2}{*}{ No. } & \multicolumn{2}{|r|}{1} & \multicolumn{2}{|r|}{2} \\
\hline & $\delta_{\mathrm{C}}$ & $\delta_{\mathrm{H}}(J$ in $\mathrm{Hz})$ & $\delta_{\mathrm{C}}$ & $\delta_{\mathrm{H}}(J$ in $\mathrm{Hz})$ \\
\hline 1 & 39.4 & 1.03 (overlap), $1.56(\mathrm{~m})$ & 39.0 & 1.03 (overlap), $1.58(\mathrm{~m})$ \\
\hline 2 & 26.6 & 1.82 (overlap), 1.98 (overlap) & 26.7 & 1.83 (overlap), 2.01 (overlap) \\
\hline 3 & 89.4 & $3.08(\mathrm{dd}, 4.8,12 \mathrm{~Hz})$ & 89.3 & $3.09(\mathrm{dd}, 4.8,12 \mathrm{~Hz})$ \\
\hline 4 & 40.1 & & 40.2 & \\
\hline 5 & 55.7 & 0.87 (overlap) & 55.7 & 0.87 (overlap) \\
\hline 6 & 18.6 & 1.21 (overlap), 1.43 (overlap) & 18.5 & 1.21 (overlap), 1.42 (overlap) \\
\hline 7 & 37.0 & 1.64 (overlap), 1.79 (overlap) & 37.0 & 1.62 (overlap), 1.76 (overlap) \\
\hline 8 & 39.6 & & 39.6 & \\
\hline 9 & 47.2 & $2.66(\mathrm{dd}, 4.8,11.4 \mathrm{~Hz})$ & 47.2 & 2.64 (overlap) \\
\hline 10 & 37.6 & & 37.5 & \\
\hline 11 & 23.4 & 1.92 (overlap), 2.07 (overlap) & 23.4 & 2.02 (overlap), 2.08 (m) \\
\hline 12 & 128.9 & 5.98 (brs) & 129.6 & $5.96(\mathrm{brs})$ \\
\hline 13 & 134.2 & & 133.3 & \\
\hline 14 & 56.9 & & 56.8 & \\
\hline 15 & 26.4 & $2.20(\mathrm{~d}, 11.4 \mathrm{~Hz}), 2.54(\mathrm{~m})$ & 26.2 & $2.20(\mathrm{~d}, 12 \mathrm{~Hz}), 2.52$ (overlap) \\
\hline 16 & 25.6 & $2.30(\mathrm{~m}), 2.56(\mathrm{~m})$ & 25.5 & $2.40(\mathrm{~m}), 2.53$ (overlap) \\
\hline 17 & 48.8 & & 49.0 & \\
\hline 18 & 55.0 & $2.78(\mathrm{~d}, 11.4 \mathrm{~Hz})$ & 54.7 & $2.68(\mathrm{~d}, 12 \mathrm{~Hz})$ \\
\hline 19 & 37.8 & 1.40 (overlap) & 37.5 & $1.38(\mathrm{~m})$ \\
\hline 20 & 39.0 & 1.03 (overlap) & 39.1 & 0.86 (overlap) \\
\hline 21 & 30.7 & $1.33(\mathrm{~m})$ & 30.3 & $1.29(\mathrm{~m})$ \\
\hline 22 & 37.2 & $1.96(\mathrm{~m})$ & 36.4 & $1.70(\mathrm{~m}), 1.88$ (overlap) \\
\hline 23 & 28.1 & $1.20(\mathrm{~s})$ & 28.0 & $1.22(\mathrm{~s})$ \\
\hline 24 & 17.0 & $1.08(\mathrm{~s})$ & 17.0 & $1.08(\mathrm{~s})$ \\
\hline 25 & 16.5 & $0.81(\mathrm{~s})$ & 16.6 & $0.85(\mathrm{~s})$ \\
\hline 26 & 18.9 & $1.05(\mathrm{~s})$ & 19.2 & $1.17(\mathrm{~s})$ \\
\hline 27 & 178.1 & & 178.0 & \\
\hline 28 & 180.6 & & 176.5 & \\
\hline 29 & 18.3 & $1.19(\mathrm{~d}, 6 \mathrm{~Hz})$ & 18.2 & $1.13(\mathrm{~d}, 6 \mathrm{~Hz})$ \\
\hline 30 & 21.4 & $0.79(\mathrm{~d}, 6 \mathrm{~Hz})$ & 21.2 & $0.74(\mathrm{~d}, 6 \mathrm{~Hz})$ \\
\hline $1^{\prime}$ & 104.5 & $4.80(\mathrm{~d}, 7.2 \mathrm{~Hz})$ & 104.7 & $4.80(\mathrm{~d}, 6.6 \mathrm{~Hz})$ \\
\hline $2^{\prime}$ & 80.1 & $4.98(\mathrm{t}, 7.2 \mathrm{~Hz})$ & 80.3 & $4.97(\mathrm{t}, 6.6 \mathrm{~Hz})$ \\
\hline $3^{\prime}$ & 77.1 & $4.36(\mathrm{t}, 8.4 \mathrm{~Hz})$ & 77.5 & 4.32 (overlap) \\
\hline $4^{\prime}$ & 70.6 & $4.15(\mathrm{~m})$ & 70.9 & $4.10(\mathrm{~m})$ \\
\hline $5^{\prime}$ & 65.8 & $3.65(\mathrm{~m}), 4.23(\mathrm{dd}, 4.8,11.4 \mathrm{~Hz})$ & 66.0 & $3.64(\mathrm{~m}), 4.22(\mathrm{t}, 10.8 \mathrm{~Hz})$ \\
\hline $1^{\prime \prime}$ & & & 95.7 & $6.34(\mathrm{~d}, 7.8 \mathrm{~Hz})$ \\
\hline $2^{\prime \prime}$ & & & 74.2 & 4.20 (overlap) \\
\hline $3^{\prime \prime}$ & & & 78.9 & 4.29 (overlap) \\
\hline $4^{\prime \prime}$ & & & 71.3 & 4.35 (overlap) \\
\hline $5^{\prime \prime}$ & & & 79.3 & $4.03(\mathrm{~m})$ \\
\hline $6^{\prime \prime}$ & & & 62.4 & $4.37(\mathrm{~m}), 4.46(\mathrm{~m})$ \\
\hline
\end{tabular}
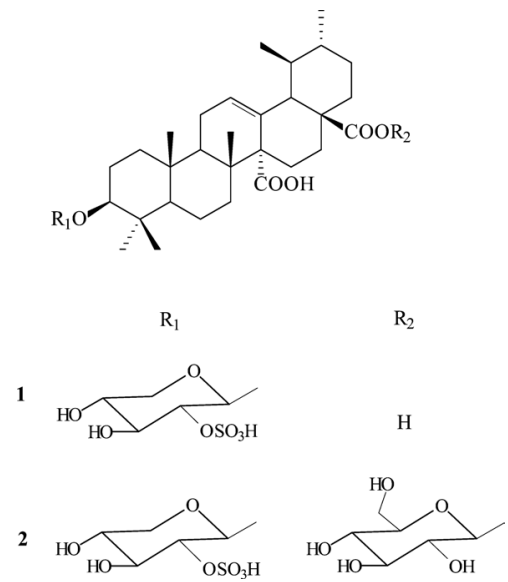

Fig. 1. Structures of Compounds $\mathbf{1}$ and $\mathbf{2}$

at $\delta 104.7$ and 95.7 , indicating the presence of two sugar moieties. The anomeric carbon signal at $\delta 95.7$ showed that one sugar residue was bonded to the aglycone by an ester bond. The anomeric proton signals were observed at $\delta 4.80$ $\left(1 \mathrm{H}, \mathrm{d}, J=6.6 \mathrm{~Hz}, \mathrm{H}-1^{\prime}\right)$ and $6.34\left(1 \mathrm{H}, \mathrm{d}, J=7.8 \mathrm{~Hz}, \mathrm{H}-1^{\prime \prime}\right)$ showed the $\beta$-configuration of sugar moieties. A comparison of the ${ }^{13} \mathrm{C}$-NMR spectrum of $\mathbf{2}$ with that of $\mathbf{1}$ showed that the chemical shifts due to the aglycone and sugar moiety in both saponins were almost the same, apart from the additional sugar in the form of an ester in 2 . The ${ }^{13} \mathrm{C}$-NMR signals appeared at $\delta 95.7,74.2,78.9,71.3,79.3$ and 62.4 were assigned to $\mathrm{C}-1-\mathrm{C}-6$ of glucose. The correlations for $\mathrm{H}-1{ }^{\prime \prime} / \mathrm{C}-$ $28, \mathrm{H}-16 / \mathrm{C}-28, \mathrm{H}-18 / \mathrm{C}-28$ in the HMBC spectrum showed the glucose moiety was attached at $\mathrm{C}-28$ of the quinovic acid. The ${ }^{1} \mathrm{H}$ - and ${ }^{13} \mathrm{C}$-NMR spectral data matched well with those reported for the 28-O- $\beta$-D-glucopyranosyl ester of quinovic acid. ${ }^{3)}$ The above structural elucidation of $\mathbf{2}$ was further supported by its ${ }^{1} \mathrm{H}-{ }^{1} \mathrm{H}$ COSY, HMQC and HMBC data. From these results, the structure of 2 (Fig. 1) was established as $3 \beta$-[(2- $O$-sulfo- $\beta$-D-xylopyranosyl)oxy]urs-12-ene-27,28dioic acid $28-\beta$-D-glucopyranoside.

Compounds $\mathbf{1}$ and $\mathbf{2}$ had been tested for their ability to inhibit nitric oxide (NO) production in a (LPS) lipopolysaccha- 
ride and recombinant mouse interferon- $\gamma$ (IFN- $\gamma$ ) activated murine macrophage like cell line RAW 264.7. Compound 1 $\left(\mathrm{IC}_{50}=113.2 \mu \mathrm{M}\right)$ showed somewhat weaker inhibition than quercetin $\left(\mathrm{IC}_{50}=24.8 \mu \mathrm{M}\right)$. Compound $2\left(\mathrm{IC}_{50}>200 \mu \mathrm{M}\right)$ had no activity. Quercetin is reported to have an inhibitory effect on the production of NO by LPS stimulated macrophage cell RAW 264.7. ${ }^{5,6)}$ Compound 1 didn't exhibit any cytotoxicity.

\section{Experimental}

General Melting points were determined using a Fisher Johns apparatus and are uncorrected. IR spectra were obtained in $\mathrm{KBr}$ disks on a PerkinElmer $983 \mathrm{G}$ spectrophotometer. NMR spectra were recorded on a INOVA 400 spectrometer. EI-MS, ESI-MS and HR-FAB-MS were recorded in a Micromass ZabSpec spectrometer. GLC was carried out on a TSQ7000 (Finnigan) GC-MS instrument. TLC employed precoated Silica gel plates (5$7 \mu \mathrm{m}$, Qingdao Haiyang). For column chromatography, Silica gel (H, 200 300 mesh, Qingdao Haiyang), Sephadex LH-20 (Pharmacia) and Macroporous resin D101 (26-60 mesh, Tianjin Haiguang Chemistry Company, Tianjin, China) were used.

Plant Material The barks of Zygophyllum fabago L. were collected from Wulumuqi, Xinjiang Autonomous Region of China in March 2004, and identified by Prof. Guo-Qiang Li of Institute of Medicinal Plant Development, Chinese Academy of Medical Sciences \& Peking Union Medical College, China, where a voucher sample has been deposited.

Extraction and Isolation The air-dried, powdered barks $(4 \mathrm{~kg})$ of the plant material were successively extracted with $75 \%$ EtOH (each $651 \times 3$ ) under reflux. The resultant extract was combined and dried under reduced pressure to give concentrated extractives $(200 \mathrm{~g})$. The latter was subsequently suspended in water and partitioned successively with $\mathrm{CHCl}_{3}, \mathrm{EtOAc}$ and $n$-butanol. The 1-butanol part $(60 \mathrm{~g})$ was subjected to column chromatography by a combination of $\mathrm{D}_{101}$ macroporous resin, eluted gradiently with $\mathrm{H}_{2} \mathrm{O}, 10 \% \mathrm{EtOH}, 30 \% \mathrm{EtOH}, 50 \% \mathrm{EtOH}, 75 \% \mathrm{EtOH}, 95 \% \mathrm{EtOH}$, successively. The fraction eluted with $30 \% \mathrm{EtOH}(11 \mathrm{~g})$ was subjected to a silica gel column with a $\mathrm{CHCl}_{3}-\mathrm{MeOH}$ gradient system $(1: 0-0: 1)$, affording 20 fractions. Fraction $9(1.3 \mathrm{~g})$ was purified by repeated ODS column chromatography $\left[\mathrm{MeOH}-\mathrm{H}_{2} \mathrm{O}(1: 1-1: 0)\right]$ to afford compound $\mathbf{1}(15 \mathrm{mg})$. Fraction $5(1 \mathrm{~g})$ was separated on Sephadex LH-20 columns with $\mathrm{MeOH}$, subsequently, further purification on an ODS column with $\mathrm{MeOH}-\mathrm{H}_{2} \mathrm{O}(2: 8-$ $1: 0)$ to provide compound $2(28 \mathrm{mg})$.

Compound 1: White powder; $\mathrm{mp} 221-223^{\circ} \mathrm{C} ;[\alpha]_{\mathrm{D}}^{20}+23.7^{\circ}(c=0.114$, $\mathrm{MeOH})$; IR $v_{\max }^{\mathrm{KBr}} \mathrm{cm}^{-1}: 3454,2939,2875,1695,1458,1388,1065,987$; ESI-MS $m / z$ : 699, 721, 743, 509; HR-ESI-MS $m / z$ : 737.2979 (Calcd for $\left.\mathrm{C}_{35} \mathrm{H}_{54} \mathrm{O}_{12} \mathrm{SK}, 737.2973\right) ;{ }^{1} \mathrm{H}$ - and ${ }^{13} \mathrm{C}-\mathrm{NMR}$ : see Table 1.

Compound 2: White powder; mp $202-204^{\circ} \mathrm{C} ;[\alpha]_{\mathrm{D}}^{20}+20^{\circ}(c=0.04$, $\mathrm{MeOH})$; IR $v_{\max }^{\mathrm{KBr}} \mathrm{cm}^{-1}: 3406,2929,2875,1745,1714,1458,1388,1063$, 985; ESI-MS $m / z$ : 861, 883, 905, 671, 464; HR-ESI-MS $m / z$ : 883.3769 (Calcd for $\mathrm{C}_{41} \mathrm{H}_{64} \mathrm{O}_{17} \mathrm{SNa}, 883.3762$ ); ${ }^{1} \mathrm{H}$ - and ${ }^{13} \mathrm{C}$-NMR: see Table 1 .

Acid Hydrolysis Compounds 1 and 2 Compounds 1 and 2 ( $3 \mathrm{mg}$, respectively) were hydrolyzed separately with $2 \mathrm{M} \mathrm{HCl}(0.5 \mathrm{ml})$ for $10 \mathrm{~h}$ at $95^{\circ} \mathrm{C}$. After filtration of the reaction mixture, the filtrate was evaporated under vacuum. After addition of $\mathrm{H}_{2} \mathrm{O}$, the acidic solution was evaporated again to remove $\mathrm{HCl}$. This procedure was repeated until a neutral solution was obtained, which was finally evaporated and dried in vacuo to furnish a monosaccharide residue. The residue was dissolved in pyridine $(1 \mathrm{ml})$, to which $2 \mathrm{mg}$ of L-cysteine methyl ester hydrochloride was added. The mixture was kept at $60^{\circ} \mathrm{C}$ for $2 \mathrm{~h}$ and evaporated under $\mathrm{N}_{2}$ stream and dried in vасио. The residue was trimethylsilylated with $\mathrm{N}$-trimethylsilylimidazole $(0.2 \mathrm{ml})$ for $2 \mathrm{~h}$. The mixture was partitioned between $n$-hexane and $\mathrm{H}_{2} \mathrm{O}$ ( $2 \mathrm{ml}$ each), and the $n$-hexane extract was analyzed by GC-MS under the following conditions: capillary column, DB-5 $(30 \mathrm{~m} \times 0.25 \mathrm{~mm} \times 0.25 \mu \mathrm{m})$; detection, FID; detector temperature, $280^{\circ} \mathrm{C}$; injection temperature, $250^{\circ} \mathrm{C}$; initial temperature was maintained at $100^{\circ} \mathrm{C}$ for $2 \mathrm{~min}$ and then raised to $280^{\circ} \mathrm{C}$ at the rate of $10^{\circ} \mathrm{C} / \mathrm{min}$, and final temperature was maintained for 5 min; carrier, $\mathrm{N}_{2}$ gas. The peak of the hydrolysate of 1 was detected at $15.48 \mathrm{~min}$ (D-xylcose) by comparison with authentic sample. The peaks of Dxylcose $(15.48 \mathrm{~min})$ and D-glucose $(24.87 \mathrm{~min})$ were detected in the hydrolysate of 2 by the same method. The aglycones were both identified as quinovic acid on thin-layer chromatography (TLC) by comparison with the authentic sample which had been isolated. ${ }^{7)}$

Detection of the Sulfate Group A 1-2 mg aliquot of each sample was refluxed with $10 \% \mathrm{HCl}(4 \mathrm{ml})$ for $4 \mathrm{~h}$ and then extracted with $\mathrm{Et}_{2} \mathrm{O}$. An aliquot of the aqueous layer of each was treated with $70 \% \mathrm{BaCl}_{2}$ to give a white precipitate $(\mathrm{BaSO} 4)^{8}{ }^{8}$

Inhibitory Activity on NO Production from Activated MacrophagesLike Cell Line, RAW 264.7 The cells were seeded at $1.2 \times 10^{6}$ cells $/ \mathrm{ml}$ onto 96-well flat bottom plate (Sumitomo Bakelite, \#8096R, Tokyo) and then incubated at $37^{\circ} \mathrm{C}$ for $2 \mathrm{~h}$. Next, the test extract was added to the culture simultaneously with both Escherichia coli LPS $(100 \mathrm{ng} / \mathrm{ml})$ and recombinant mouse IFN- $\gamma(0.33 \mathrm{ng} / \mathrm{ml})$. Then cells were incubated at $37^{\circ} \mathrm{C}$ for approximately $16 \mathrm{~h}$ and subsequently chilled on ice. One hundred microliters of the culture supernatant was placed in duplicate in the wells of 96-well flat bottomed plates. A standard solution of $\mathrm{NaNO}_{2}$ was placed in alternate wells on the same plate. To quantify nitrite, $50 \mu 1$ of Griess reagent ( $1 \%$ sulfanilamide in $5 \% \mathrm{H}_{3} \mathrm{PO}_{4}$ and $0.1 \% \mathrm{~N}$-1-naphthyletyl-enediamide dihydrochloride) was added to each well. After $10 \mathrm{~min}$ the reaction products were colorimetrically quantified at $550 \mathrm{~nm}$ using a Model 3550 Microplate Reader (BIO-RAD) and the background absorbance $(630 \mathrm{~nm})$ was subtracted. Cytotoxicity was measured by the 3-(4,5-dimethythiazol-2-yl)-2,5-diphenyltetrazolium bromide (MTT) assay method.

\section{References}

1) Jiangsu Institute of Botany, Chinese Academy of Medical Sciences and Kunming Institute of Botany, "Xinhua bencao gangyao," Vol. 1, Shanghai Science and Technology Press, Shanghai, 1988, p. 272.

2) Al-Ani T. A., Habib I. M., Aziz A. I. A., Ouda N. A., Plant and Soil, 35, 29-36 (1971).

3) Viqar U. A., Ghazala S. U., Mohammad S. A., Phytochemistry, 33, 453 - 455 (1993).

4) Karl P., Stefan G. M., Hani A. E., Kamel H. S., Karlheinz S., Phytochemistry, 44, 485-489 (1997).

5) Rao M. K., Ghosh B., Int. J. Immunopharmacol., 21, 435-443 (1999).

6) Kim H. K., Cheon B. S., Kim S. Y., Kim H. P., Biochem. Pharmacol., 58, 759-765 (1999).

7) Feng Y. L., Li H. R., Xu L. Z., Yang S. L., Asian Nat. Prod. Res., 9, $505-510$ (2007).

8) Akai E., Takeda T., Kobayashi Y., Ogihara Y.. Chem. Pharm. Bull., 33, 3715-3723 (1985). 